\title{
Sex-based Short-term Memory of Vocabulary Trained with Pease and Pease's Multimodality
}

\author{
Hasan Arifuddin \\ Language and Art Department Faculty of Education University of Mataram, \\ Majapahit Street Mataram Lombok Indonesia. \\ E-mail: arifpgn@yahoo.com
}

Accepted: November 02, 2012 Published: December 22, 2012

Doi:10.5296/ijhrs.v2i4.2730

URL: http://dx.doi.org/10.5296/ijhrs.v2i4.2730

\begin{abstract}
Rose and Nicholl's theory dealing with the effectiveness of multisensory learning seems contradictory with Pease and Pease's theory regarding with gender-based multitasking. The present study aims at: 1) determining the significance of the difference of STM of English vocabulary between males and females trained with different types of modality; 2) testing whether multimodality lowers males' STM of English vocabulary; and 3) exploring the trainees' modality preference and their reasons based on sex. This mix-methods study involved 60 subjects drawn through Allocation Random Sampling from the entire freshmen. Data were collected with tests, a structured questionnaire, an interview, a tape-recorder, observations and note-taking. They were analyzed with Two-way Anova, Chi-square $\left(\chi^{2}\right)$ and cyclical qualitative analysis. It shows that: 1) there is a significant difference of STM of English vocabulary between males and females trained with different types of modality; 2) multimodality did not lower males' STM of English vocabulary; and 3) Pease and Pease's theory is not accepted. The determinants of their modality preference are the effectiveness of a certain type of modality, their learning habits and their school regulations.
\end{abstract}

Key words: Multitasking, Multimodality, Sex, Short-term memory, Training, Development

\section{Introduction}

Vocabulary mastery is the pre-requisite for language proficiency. As a requirement for language proficiency, vocabulary is always one of the targets of a language training. But, "How to improve the trainees' vocabulary mastery?" A commonly heard statement could be, "It is not easy to improve trainees' vocabulary mastery in a language training." Until recently, English language trainers may still be uncertain about which type of teaching modality is effective in vocabulary building based on sex. Consequently, in teaching vocabulary to freshmen in particular, the trainers tend to apply conventional language 
teaching methods/techniques. They apply multitasking (or multimodality), the involvement of more than one sense or activity simultaneously, in teaching all language skills. They also consistently follow Rose and Nicholl's (2003) theory suggesting that the more senses involved, the more effective the learning process will be. This theory is contradictory with Pease and Pease's (2006) theory proposing that a man can only do one activity, or involve one sense, task or modality, at a certain point of time, while females can do more activities simultaneously. It implies that multimodality is not an effective learning strategy for males. This is a debatable theory.

Besides, the two pairs of scholars have not explicitly considered the difference of males' and females' brain capacity in language processing. Neurologically, female's brain language capacity is superior to male's. The following are, among others, research findings indicating females' brain superiority to males'. First of all, Arifuddin's (2005) study on hemispheric language capacity showed that women outperfomed men in identifying topics of associated English words. Closely related to it, Arifuddin and Sujana's (2010) study also showed that women's hemispheric capacity in inferring sentences and dialogues is higher than men's. Chaer (2003) also expresses that a woman's sight, hearing and memory is better than man's and a plenty of studies indicate that women's memory is better than men's.

However, none of those theories and studies focused on short-term memory (hereafter STM) -- defined as the memory performance during the act of learning (Bruning, et.al, 2004:14) based on the formula of STM capacity 'seven plus or minus 2' (Miller's range of items) -- of English vocabulary on the basis of sex. Accordingly, the present study aimed at: 1) determining the significance of the difference of STM of English vocabulary between males and females trained with different types of modality; 2) testing whether multimodality (or multitasking) lowers males' STM of English vocabulary; and 3) exploring the trainees' preference to certain learning modalities and their reasons based on sex.

As a matter of fact, language trainers have not seriously taken into consideration the trainees' neurological differences and preferences to certain learning modalities applied in language trainings. Explicitly, a language trainer should not blindly force his or her trainees, who have been identified as having diverse brain capacities, to process homogeneous language input.

Theoretically, the present study provided the new findings regarding the effectiveness of multimodality in improving vocabulary memory based on sex. It also informs whether male learners are categorized as either unitasking or multitasking humanbeings with regard to their rate of STM of English vocabulary achieved in language training learned through different types of modality. This finding clarified whether Pease and Pease's (2006) theory is acceptable in the context of STM of vocabulary. Admittedly, this is one of the novelties of the present study. Practically, the effectiveness of each type of modality in an English language training should be taken into account and the trainees' neurological and biological attributes are also worthy considering. I am sure that the products of the present 
study are definitely meaningful for human resources development, e.g. through a language training.

\section{Method}

This is a mixed-method study conducted to determine the significance of the difference of STM of English vocabulary between males and females trained through different combinations of modalities; test whether Pease and Pease's (2006) theory is acceptable related to rate of STM of vocabulary achieved through the implementation of three types of modality and explore the trainees' preference to certain learning modalities and their reasons based on sex. This section presents design, variables, subjects, instruments, and procedures (data collection and data analysis). The simplified flow chart of the research design is as follows.

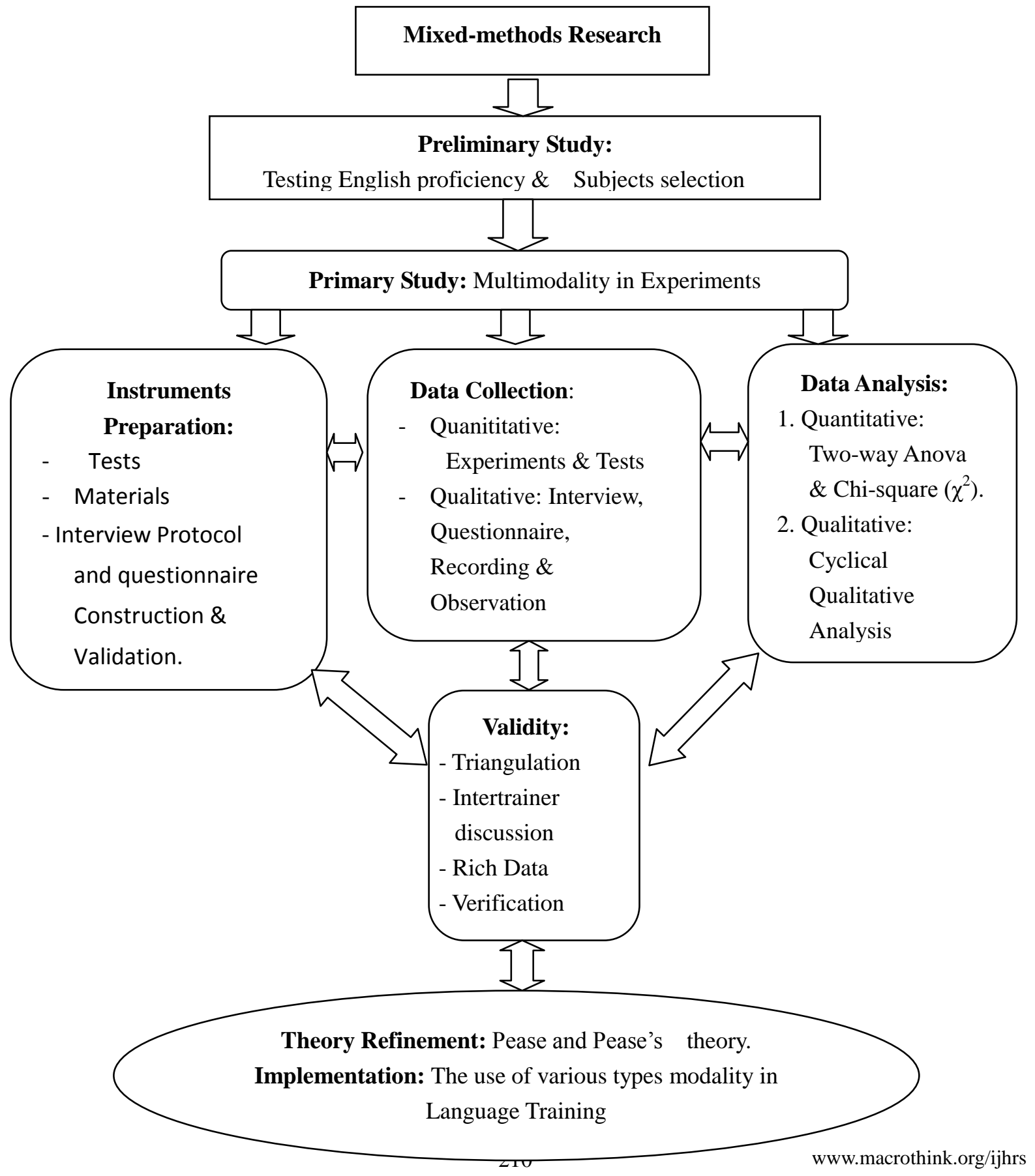


2.1 Variables

2012, Vol. 2, No. 4

2.1.1 Dependent variables include STM of vocabulary and modality preference.

2.1.2 Independent variables involve sex (male vs. female) and types of modality.

\subsection{Subjects}

The population of the present study involved all freshmen of both Mens Junior High School and Womens Junior High School of Islamic Boarding School Haramain Narmada Indonesia. Prior to the regular classroom activities, they need to attend an entrance English training. This is a kind of preliminary human resources development training for the freshmen of Islamic schools. In their lower school level, elementary schools, English has never been introduced, so they are in the level of zero English proficiency. To make sure, the English vocabulary mastery of the population was firstly tested with researcher-made vocabulary tests prior to the training. Vocabulary taught in the training were limited only on the unknown ones. The sample of the subjects with zero English proficiency was drawn through Equal Allocation Random Sampling technique. The sample size was larger than 10 percent, 30 students from Mens Boarding School and Womens Boarding School respectively, from the entire population as Furchan (1982) and Arikunto (1993) suggest.

\subsection{Instruments}

As mentioned earlier, the subjects were selected from the population of the freshmen using researcher-made vocabulary test. Vocabulary tests administered immediately after the implementation of every type of modality were used to collect data about STM of English vocabulary, and a structured questionnare, an interview, a tape-recorder, an observation and note-taking were employed to explore data about modality preferences.

\subsection{Procedures}

\subsubsection{Data Collection}

The present study employed factorial design $2 \times 3$ because it involved two attribute variables, male and female as 'level' and three types of modality: 1) Seeing (unimodality), 2) Seeing + Hearing (bimodality), and 3) Seeing + Hearing + Writing (multimodality) as independent variables. The vocabulary training focused on unknown vocabulary that the researcher selected and taught in the same frequency using the three types of modality. To test STM, the tests were administered immediately at the end of the implementation of every type of modality. Their scores were recorded and tabulated. As mentioned in 2.3, data about modality preference were collected with a structured questionnaire, an interview, a tape-recorder, an observation and note-taking.

\subsubsection{Data Analysis}

Data were analyzed with Two-way Anova, SPSS 11.5 program to compute the difference of STM of English vocabulary rate based on sex and different types of modality. Data about modality preference were analyzed with Chi-square $\left(\chi^{2}\right)$ (Sugiyono, 2003) and their reasons were analyzed with cyclical qualitative analysis (Yin, 2011). 


\section{Result and Discussion}

This section contains Null Hypothesis, STM through Modality, and Modality Preference.

\subsection{Null Hypothesis}

The Null Hypotheses include: 1) There is no significant difference of STM of English vocabulary between males and females trained with different types of modality; 2) Multimodality does not lower males' English vocabulary STM; and 3) There is no similarity of modality preference between male and female trainees.

\subsection{STM through Multimodality}

To begin with, the following are mean scores of six-time English vocabulary training, each of which was immediately followed by a test of STM of English vocabulary.

Table 1. Mean Scores of Males' STM of English Vocabulary

\begin{tabular}{|c|c|c|c|c|c|}
\hline \multicolumn{3}{|c|}{ Mean Scores } & \multicolumn{3}{|c|}{ Mean Scores } \\
\hline Seeing & $\begin{array}{c}\text { Seeing + } \\
\text { Listening }\end{array}$ & $\begin{array}{c}\text { Seeing + Listening } \\
+ \\
\text { Writing }\end{array}$ & Seeing & $\begin{array}{c}\text { Seeing + } \\
\text { Listening }\end{array}$ & $\begin{array}{c}\text { Seeing + } \\
\text { Listening + } \\
\text { Writing }\end{array}$ \\
\hline 7.5 & 10 & 10 & 7 & 8 & 9.5 \\
\hline 6 & 8 & 10 & 8 & 9.5 & 8.5 \\
\hline 5 & 7 & 8 & 7 & 7.5 & 9 \\
\hline 8 & 8 & 9 & 5 & 7 & 8 \\
\hline 6 & 7.5 & 9 & 5 & 7 & 8 \\
\hline 7 & 9.5 & 10 & 7 & 9 & 10 \\
\hline 7.5 & 6.5 & 9 & 8 & 7.5 & 8 \\
\hline 8 & 8 & 9.5 & 9 & 9 & 9.5 \\
\hline 7.5 & 9 & 9.5 & 9 & 9.5 & 10 \\
\hline 4.5 & 8 & 9 & 9 & 8 & 9.5 \\
\hline 7 & 7.5 & 9 & 8.5 & 8 & 10 \\
\hline 5 & 8 & 7.5 & 9 & 9 & 8.5 \\
\hline 5 & 7 & 9 & 8.5 & 9 & 10 \\
\hline 7 & 8 & 9.5 & 6.5 & 4.5 & 6 \\
\hline 7 & 8 & 9.5 & 10 & 10 & 10 \\
\hline 8 & 9.5 & 8.5 & 7 & 10 & 8 \\
\hline 7 & 7.5 & 9 & 5 & 7.5 & 9 \\
\hline 5 & 8 & 7.5 & 217.5 & 252 & 279.5 \\
\hline 5 & 7 & 9 & 7.000 & 8.1290 & 9.0161 \\
\hline 7 & 8 & 9.5 & & & \\
\hline
\end{tabular}

Table 2. Mean Scores of Females' STM of English Vocabulary

\begin{tabular}{|c|c|c|c|c|c|c|}
\hline \multicolumn{3}{|c|}{ Mean Scores } & & \multicolumn{3}{c|}{ Mean Scores } \\
\cline { 5 - 6 } \cline { 5 - 6 } & & Seeing + Listening & & & Seeing + \\
Seeing & Seeing + & + & & Seeing + & Listening + \\
Listening & Writing & & Seeing & Listening & Writing \\
\hline
\end{tabular}




\begin{tabular}{|c|c|c|}
\hline 10 & 10 & 10 \\
\hline 7.5 & 7.5 & 10 \\
\hline 9 & 9 & 9 \\
\hline 9.5 & 9.5 & 10 \\
\hline 8 & 8 & 10 \\
\hline 8 & 9.5 & 9.5 \\
\hline 6 & 7 & 10 \\
\hline 7.5 & 8.5 & 9.5 \\
\hline 8.5 & 6.5 & 8 \\
\hline 10 & 10 & 10 \\
\hline 7 & 9 & 10 \\
\hline 8.5 & 10 & 10 \\
\hline 7.5 & 9 & 10 \\
\hline 8 & 10 & 10 \\
\hline 9 & 8.5 & 10 \\
\hline 8 & 9.5 & 10 \\
\hline & & \\
\hline
\end{tabular}

\begin{tabular}{|c|c|c|}
\hline 10 & 10 & 10 \\
\hline 8.5 & 9.5 & 8.5 \\
\hline 7.5 & 10 & 10 \\
\hline 8.5 & 9.5 & 10 \\
\hline 8.5 & 10 & 10 \\
\hline 10 & 10 & 10 \\
\hline 6.5 & 10 & 10 \\
\hline 8.5 & 10 & 9.5 \\
\hline 7.5 & 10 & 10 \\
\hline 6.5 & 7 & 9 \\
\hline 8.5 & 10 & 10 \\
\hline 8 & 9 & 10 \\
\hline 7.5 & 8.5 & 10 \\
\hline 8.5 & 9 & 9.5 \\
\hline 8.5 & 9.5 & 9.5 \\
\hline $\mathbf{2 5 5}$ & $\mathbf{2 8 3 . 5}$ & $\mathbf{3 0 2}$ \\
\hline $\mathbf{8 . 2 2 5 8}$ & $\mathbf{9 . 1 4 5 2}$ & $\mathbf{9 . 7 4 1 9}$ \\
\hline
\end{tabular}

The following are the summaries of the total scores and mean scores of each types of learning modality derived from the 6 tests according sex.

Table 3. Total Scores and Mean Scores of Vocabulary Memory

\begin{tabular}{|c|c|c|c|c|}
\hline & Seeing & Seeing + Hearing & $\begin{array}{c}\text { Seeing + Hearing + } \\
\text { Writing }\end{array}$ & Mean \\
\hline Male & $\begin{array}{c}217.5 \\
(7.081)\end{array}$ & $\begin{array}{c}252 \\
(8.129)\end{array}$ & $\begin{array}{c}279.5 \\
(9.016)\end{array}$ & 8.075 \\
\hline Female & $\begin{array}{c}255 \\
(8.226)\end{array}$ & $\begin{array}{c}283.5 \\
(9.145)\end{array}$ & $\begin{array}{c}302 \\
(9.742)\end{array}$ & 9.038 \\
\hline
\end{tabular}

Since the present study used parametric data, the normality and homogeneity of the data should be tested. Using SPSS program, the result of test of normality is as follows.

Table 4. Tests of Normality

\begin{tabular}{|l|l|r|r|r|r|r|r|}
\hline & X & \multicolumn{3}{|c|}{ Kolmogorov-Smirnov(a) } & \multicolumn{3}{|c|}{ Shapiro-Wilk } \\
\hline & & Statistic & \multicolumn{1}{c|}{ Df } & \multicolumn{1}{c|}{ Sig. } & Statistic & \multicolumn{1}{c|}{ Df } & \multicolumn{1}{c|}{ Sig. } \\
\hline Y1 & 1.00 & .156 & 31 & .057 & .941 & 31 & .086 \\
\hline & 2.00 & .188 & 31 & .068 & .925 & 31 & .058 \\
\hline & 3.00 & .203 & 31 & .062 & .868 & 31 & .071 \\
\hline Y2 & 1.00 & .169 & 31 & .054 & .946 & 31 & .121 \\
\hline & 2.00 & .217 & 31 & .070 & .809 & 31 & .070 \\
\hline & 3.00 & .408 & 31 & .080 & .596 & 31 & .058 \\
\hline
\end{tabular}

a Lilliefors Significance Correction

The levels of significance $p$ of the three types of learning modalities (Unimodality, bimodality and multimodality) for each sex tested with Kolmogorov-Semirnov (Lilifors Significance Correction) are .057; .068; .062; .54; .070; and .080 respectively and all levels of significance are higher than $\alpha=.05$. Therefore, the 
three pairs of scores are normally distributed.

The next procedure is testing homogeneity of the data using Based on Mean of Levene Statistic.

Table 5. Test of Homogeneity of Variance

\begin{tabular}{|c|c|c|c|c|c|}
\hline & & $\begin{array}{l}\text { Levene } \\
\text { Statistic }\end{array}$ & df1 & df 2 & Sig. \\
\hline \multirow[t]{4}{*}{$\mathrm{Y1}$} & Based on Mean & 3.261 & 2 & 90 & .073 \\
\hline & $\begin{array}{l}\text { Based on } \\
\text { Median }\end{array}$ & 3.034 & 2 & 90 & .057 \\
\hline & $\begin{array}{lr}\text { Based on } \\
\text { Median and } \\
\text { with adjusted df }\end{array}$ & 3.034 & 2 & 83.311 & .057 \\
\hline & $\begin{array}{l}\text { Based on } \\
\text { trimmed mean }\end{array}$ & 3.189 & 2 & 90 & .059 \\
\hline \multirow[t]{4}{*}{$\mathrm{Y} 2$} & Based on Mean & 6.528 & 2 & 90 & .123 \\
\hline & $\begin{array}{ll}\text { Based } & \text { on } \\
\text { Median } & \\
\end{array}$ & 6.004 & 2 & 90 & .056 \\
\hline & $\begin{array}{lr}\text { Based } \\
\text { Median and } \\
\text { with adjusted df }\end{array}$ & 6.004 & 2 & 81.226 & .056 \\
\hline & $\begin{array}{l}\text { Based on } \\
\text { trimmed mean }\end{array}$ & 6.783 & 2 & 90 & .068 \\
\hline
\end{tabular}

The result of the test provides the levels of significance $p$ of the scores of vocabulary memory shown by male trainees and female trainees, .073 and $\quad .123$ respectively. Since $p>\alpha(.05)$, those scores of vocabulary tests are homogeneous and, consequently, they fulfill the requirement of parametric statistics. Levene statistic test showed that F value of Y1 was 3.261 with significance level .073 and $F$ value of Y2 was 6.528 with significance level .123. Because the significance levels of Y1 and $\mathrm{Y} 2$ are higher than that of $\alpha(.05)$, the $\mathrm{F}$ value is not significant (Determining level of significance applied in error variance procedure is 'reversed' from the one commonly used in other procedures). Therefore, Y1 and Y2 had homogeneous variance, and then parametric analysis can be continued. Firstly, data are tested with Box's test of equality of covariance matrices.

Table 6. Box's Test of Equality of Covariance Matrices(a)

\begin{tabular}{|l|r|}
\hline Box's M & 24.599 \\
\hline F & 3.968 \\
\hline df1 & 6 \\
\hline df2 & 201876.92 \\
& 3 \\
\hline Sig. & .081 \\
\hline
\end{tabular}

Tests the null hypothesis that the observed covariance matrices of the dependent 
variables are equal across groups.

a Design: Intercept $+X$

The Box's M value was 24.599 with significance level .081. Since higher than .05 , its significance value was not significant. The result of Box's M test indicated the significant difference of STM of English vocabulary between male and female trainees trained with three different modalities. Using the 'reversed' principle of determining level of significance, the difference of vocabulary memory between male students (Y1) and female students (Y2) is significant.

Table 7. Multivariate Tests(c)

\begin{tabular}{|l|l|r|r|r|r|r|}
\hline Effect & & \multicolumn{1}{c|}{ Value } & \multicolumn{1}{c|}{$\mathrm{F}$} & \multicolumn{1}{c}{ Hypothesis df } & \multicolumn{1}{c|}{ Error df } & \multicolumn{1}{c|}{ Sig. } \\
\hline Intercept & Pillai's Trace & .994 & $7121.166(\mathrm{a})$ & 2.000 & 89.000 & .002 \\
\hline & $\begin{array}{l}\text { Wilks' } \\
\text { Lambda }\end{array}$ & .006 & $7121.166(\mathrm{a})$ & 2.000 & 89.000 & .002 \\
\hline & $\begin{array}{l}\text { Hotelling's } \\
\text { Trace }\end{array}$ & 160.026 & $7121.166(\mathrm{a})$ & 2.000 & 89.000 & .002 \\
\hline & $\begin{array}{l}\text { Roy's } \\
\text { Largest Root }\end{array}$ & 160.026 & $7121.166(\mathrm{a})$ & 2.000 & 89.000 & .002 \\
\hline & Pillai's Trace & .499 & 14.962 & 4.000 & 180.000 & .002 \\
\hline & $\begin{array}{l}\text { Wilks' } \\
\text { Lambda }\end{array}$ & .502 & $18.335(\mathrm{a})$ & 4.000 & 178.000 & .004 \\
\hline & $\begin{array}{l}\text { Hotelling's } \\
\text { Trace }\end{array}$ & .993 & 21.837 & 4.000 & 176.000 & .015 \\
\hline & $\begin{array}{l}\text { Roy's } \\
\text { Largest Root }\end{array}$ & .991 & $44.612(\mathrm{~b})$ & 2.000 & 90.000 & .004 \\
\hline
\end{tabular}

a Exact statistic

$\mathrm{b}$ The statistic is an upper bound on $\mathrm{F}$ yielding a lower bound on the significance level.

c Design: Intercept $+\mathrm{X}$

Besides, the F values obtained through all tests, Pillai"s Trace, Wilks" Lambda, Hotelling's Trace, Roy's Largets Root, are lower than .05. It means that F values of Pillai"s Trace, Wilks" Lambda, Hotelling's Trace, Roy's Largets Root are not significant. This result is also supported by the interaction effect of the independent variables shown in the following table.

Table 8. Tests of Between-Subjects Effects

\begin{tabular}{|l|c|r|r|r|r|r|}
\hline Source & $\begin{array}{l}\text { Dependent } \\
\text { Variable }\end{array}$ & $\begin{array}{l}\text { Type III } \\
\text { Sum of } \\
\text { Squares }\end{array}$ & \multicolumn{1}{c|}{ df } & Mean Square & \multicolumn{1}{c|}{ F } & \multicolumn{1}{c|}{ Sig. } \\
\hline $\begin{array}{l}\text { Corrected } \\
\text { Model }\end{array}$ & Y1 & $58.199(\mathrm{a})$ & 2 & 29.099 & 19.289 & .003 \\
\hline & Y2 & $36.167(\mathrm{~b})$ & 2 & 18.083 & 23.101 & .003 \\
\hline Intercept & Y1 & 6064.527 & 1 & 6064.527 & 4019.964 & .032 \\
\hline
\end{tabular}




\begin{tabular}{|l|r|r|r|r|r|r|}
\hline & Y2 & 7596.132 & 1 & 7596.132 & 9703.850 & .002 \\
\hline $\mathrm{X}$ & $\mathrm{Y} 1$ & 58.199 & 2 & 29.099 & 19.289 & .003 \\
\hline & $\mathrm{Y} 2$ & 36.167 & 2 & 18.083 & 23.101 & .003 \\
\hline Error & $\mathrm{Y} 1$ & 135.774 & 90 & 1.509 & & \\
\hline & $\mathrm{Y} 2$ & 70.452 & 90 & .783 & & \\
\hline Total & $\mathrm{Y} 1$ & 6258.500 & 93 & & & \\
\hline & $\mathrm{Y} 2$ & 7702.750 & 93 & & & \\
\hline $\begin{array}{l}\text { Corrected } \\
\text { Total }\end{array}$ & Y1 & 193.973 & 92 & & & \\
\hline & Y2 & 106.618 & 92 & & & \\
\hline
\end{tabular}

a $\quad$ R Squared $=.300$ (Adjusted R Squared $=.284$ )

b $\quad$ R Squared $=.339$ (Adjusted R Squared $=.325$ ).

The $\mathrm{F}$ value obtained through Tests of Between-Subjects Effects is 19.289 with significance level .03. Based on the values, there is a significant difference of vocabulary memory level among the three types of modality for each sex (male trainees Y1 and female trainees Y2). Specific to male trainees, this is contradictory with the alternative hypothesis. In other words, the null hypothesis, "Multimodality (or multitasking) does not lower males' STM of English vocabulary" is accepted.

Based on the summary of the research data and the statistical analysis, globally, there is a significant difference of vocabulary memory rate between male trainees and female trainees trained with the three types of learning modality.

Neurologically, women usually show higher vocabulary memory than men. This is relevant to Steinberg, et al.'s (2001) research finding showing that men's and women's brain shape and structure is different, woman's LH is thicker than her RH. This physiological and cognitive factors may lead to women's brain superiority to men's. Bitan, et al. (2010) found greater interhemispheric connectivity in girls compared to boys, consistent with the hypothesis suggesting that a more bilateral representation of language is found in females than in males. Cousin et al. (2009) found that males showed an asymmetric pattern, while females showed greater symmetry. Males were significantly more lateralized than female participants. Studying about visual cortex, Proverbio et al. (2006) also found that men showed an asymmetric functioning of visual cortex while decoding faces and expressions, whereas women showed a more bilateral functioning. Burman (2008) also found gender difference for language processing in adults, showing activity in language areas on both sides of the brain for females but mostly on the left side for males.

In Press Trust of India (2007), it is reported that women's and men's brains have different capacity. For example, women's left hemisphere is thicker than their right hemisphere. Undoubtedly, a plenty of studies show that men's and women's brains work 
differently. Leopold (2008) also reports that for the first time researchers from Northwestern University and the University of Haifa found that both areas of the brain associated with language work harder in girls than in boys during language tasks, and that boys and girls rely on different parts of the brain when performing these tasks.

Pease and Pease (2006) argue that men use the left hemisphere for speaking, while women use both the right and the left hemispheres. Madaule (2002) expresses that simultaneous involvement of ears and lips (or mouth) improves memory capacity in language mastery. Similarly, Jewell (2003:18) suggests that to be able to remember experience or verbal information, say it until you clearly hear. Deux (1985) also states that men outperform women in decoding visual stimuli. While it has been commonly held that males show an advantage on spatial tasks, and females on verbal tasks, Ferguson, et al. (2007) suggest that male performance on visuo-spatial is more than female performance. Another study conducted by Leopold (2006) confirms that males and females use different parts of brain in language and visuo-spatial tasks. The differences in the way men and women perform verbal and visuo-spatial tasks have been well documented in scientific literature, but findings have been inconsistent as to whether men and women actually superior. Jensen (2007) admits that it is commonly accepted that women are superior to men in verbal memory and they process language faster and more effectively than men. Seeing, hearing, and memory of women are better than men's. Related to the level of vocabulary memory shown by male students by involving the same learning modality, Gallo-Crail and Zerekh (2002) found that most women outperformed men, and female students are superior to male students. Similarly, Shellenberger (2009) found a significant main effect for sex indicating that females did better on recall than males. Bridge, et al. (2006) also found that it would seem that gender does play a role in the usage of STM. A study on gender difference and STM carried out by Speck et al. (2000) show a higly significant gender differences in the functional organization of the brain for STM. In relation to the nature of STM expressed by Fernandez and Cairns (2011), structures, group of words (or specific details), or lexical items are held in STM, while meaning, idea, or gist is stored in LTM. To make sure, in the future it is also important to study about vocabulary memory between men and women using different visual objects.

To both male and female trainees, the more the modalities involved, the higher the level of vocabulary memory. This finding is consistent with Rose and Nicholl's (2003) view arguing that the more senses involved, the more effective the learning will be, "two is better than one". If related to vocabulary building, it leads to the higher rate of vocabulary memory. Relatively similar, Rose and Nicholl (2006) emphasise that a language learner needs to learn language by integrating visual, auditory and 
kinaesthetic inputs. Naturally, a child learns by seeing, hearing, reading, doing, and saying and these are the best ways. Some studies summarised by dePorter et al. (2000) indicated that the more modalities (visual, auditory, and kinaetsthetic) involved simultaneously, the more alive the learning, and even it leads to long term-memory. Suharsono (2005) also emphasises that it is not sufficient to learn language only by reading, it should be followed by hearing, speaking (or saying) and writing instead. In relation to biological perspective, Duyek (1996) emphasises that women can use their eyes, ears, and intuition more effectively. Those findings support the view that the more senses or modalities involved (simultaneously), the more effective the learning will be. For example, when listening, a man should not see and write what he is listening at the same point of time because it may decrease the effectiveness of his listening activity. Iddon and Williams (2005) also confirmed that women outperformed men in doing language-related activities, emotional judgement, idea expression activities, and multitasking. Jensen (2007:149) also agrees that women are able to do a variety of task simultaneously.

However, Pease and Pease's (2006) theory suggesting that a man can only do one activity effectively at a certain point of time is contradictory with the finding of the present study. Surprisingly, the present study shows that males' STM of English vocabulary trained with only one type of modality (unimodality), e.g. Seeing, is lower than the one trained through two (or bimodality) or three modalities (or multimodality).

\subsection{Modality Preference}

\subsubsection{Male Trainees' Preference}

The subjects involved 30 male trainees. The detail is as follows.

Table 9. Modality Preference of Male Trainees

\begin{tabular}{|l|c|c|c|c|}
\hline \multicolumn{1}{|c|}{ Preference } & Fo & fe & fo - fe & $\frac{(\mathbf{f o}-\mathbf{f e})^{2}}{\mathbf{f e}}$ \\
\hline Seeing & 0 & 10 & -10 & 10 \\
Seeing+Hearing & 1 & 10 & -9 & 8.1 \\
Seeing+Hearing+Writing & 29 & 10 & 19 & 36.1 \\
\hline & & & & $\sum \frac{(\mathrm{fo}-\mathrm{fe})^{2}}{\mathrm{fe}}$ \\
& & & & $=54.2$ \\
\hline
\end{tabular}

Based on the analysis above, the value of the obtained Chi-Squared $\left(\chi^{2}\right)$ is 54.2. With the degree of freedom $(\mathrm{df})=3-1=2$ and the level of significance $5 \%$, the $\chi^{2}$ table value is 5.991. Since the value of the obtained $\chi^{2}$ is higher than that of $\chi^{2}$ table ( $54.2>5.991)$, there is a significant difference of preference to the three types of learning modality in male trainees. Based on the distribution of modality preferences, the multimodality (Seeing+Hearing+Writing) is preferred. The implication is that the fact that males preferred to multitasking (multimodality) is contradictory with Pease and Pease's (2006) theory which labels males as unitasking humanbeings. 


\subsubsection{Female Trainees' Preference}

The subjects involved 30 female trainees. The detail is as follows.

Table 10. Modality Preference of Female Trainees

\begin{tabular}{|l|c|c|c|c|}
\hline Preference & Fo & Fe & fo - fe & $\frac{(\text { fo }-\mathrm{fe})^{2}}{\mathrm{Fe}}$ \\
\hline Seeing & 2 & 10 & -8 & 6.4 \\
Seeing+Hearing & 5 & 10 & -5 & 2.5 \\
Seeing+Hearing+Writing & 23 & 10 & 13 & 16.9 \\
\hline & & & & $\begin{array}{c}\Sigma(\mathrm{fo}-\mathrm{fe})^{2} \\
\mathrm{fe} \\
\end{array}$ \\
& & & & $=25.8$. \\
\hline
\end{tabular}

Based on the nonparametric analysis, the value of the obtained Chi-Squared $\left(\chi^{2}\right)$ is 25.8. With the degree of freedom (df) $=3-1=2$ and level of significance $5 \%$, the value of $\chi^{2}$ table is 5.991. Since the value of the obtained $\chi^{2}$ is higher than that of $\chi^{2}$ table $(25,8>5,991)$, there is a significant difference of preference to the three types of learning modality in female trainees. Based on the distribution of preference to modalities, Seeing+Hearing+Writing is mostly preferred.

There is a similarity of modality preference between male and female trainees. Their modality preference, that is, they tend to involve more than one learning modality simultaneously, relates to the effectiveness of a certain type of modality. Both male and female trainees preferred multimodality (Seeing+Hearing+Writing). On one hand, in general sense, there is a relation between modality preference and modality effectiveness. This modality choice is consistent with the effectiveness of the multimodality. On the other hand, to male trainees, this finding is not relevant to Pease and Pease's (2006) view indicating that men are unable to do more than one activity in the same time. The effectiveness of the multimodality in males' vocabulary learning through this method is questionable with reference to Pease and Pease's (2006) theory.

Unlike males, female trainees' preference to the involvement of more learning modalities simultaneously related to their effectiveness supports the findings of some previous studies. For example, Pease and Pease (2006) suggested that women can do more than one activity in the same time more effectively than men. The majority of the trainees are accustomed to involving more learning modalities. In the daily classroom activities, their teachers tend to suggest them to write, listen and say (or pronounce) the learning materials, including vocabulary. The teachers feel worried with their students' comprehension and memory if their students do not write the learning materials. In other words, multitasking (or multimodality) has long been their habit in learning activities. Darmowidjojo (2003) expresses that although there is a 
different ability in language processing between male and female learners, this ability is inseparable from the effect of tradition or learning habits, not absolutely due to genetic and biological impacts.

At the Haramain Islamic boarding schools, there are a plenty of outside classroom programs designed as media for improving English proficiency, including those directed to enhance the learners' vocabulary mastery. During the out-door learning programs, the learners are also accustomed to using spoken English, integrating speaking and listening skills. The school also demands the students to use English and Arabic languages around the school environment, and it is an attempt to 'boost' students' foreign language performance.

It is concluded that: 1) there is a significant difference of STM of English vocabulary between males and females trained with different types of modality; 2) multimodality did not lower males' STM of English vocabulary; and 3) there is a similarity of modality preference between male and female trainees. Both preferred multimodality (Seeing+Listening+Writing). With regard to male trainees, this finding is not relevant to Pease and Pease's (2006) view indicating that men are unable to do more than one activity in the same time. Since multimodality is effective in improving males' STM of English vocabulary, Pease and Pease's (2006) theory is not accepted. The effectiveness of a certain modality, their learning habits, and their school regulations affect their choice (or preference) of modality.

\section{Acknowledgement}

I am so greatful to DP2M Directorate General of Higher Education Republic of Indonesia and University of Mataram sponsoring this research.

\section{References}

Arifuddin and Sujana, I.M. (2010). 'Consistency of hemispheric accuracy in inferring sentences and dialogs'. K@ta Journal. 12(1). 15-25.

Arifuddin. (2005). Hemispheric accuracy of English Education Students University of Mataram in identifying topics of auditory associated English word groups. Masters Degree Thesis. Jurnal Ilmiah Pendidikan dan Pembelajaran Program Pasca Sarjana IKIP Negeri Singaraja (Scientific Journal of Education and Learning of Postgraduate Program State Institute of Education Singaraja). 2(2). 380-394. Singaraja: IKIP Negeri Singaraja.

Arikunto, S. (1993). Prosedur penelitian (Research procedures). Jakarta: PT Rineka Cipta.

Bitan, T., Lifshitz, A. Breznitz, Z. and Booth, J. R. (2010). 'Bidirectional connectivity between hemispheres occurs at multiple levels in language processing but depends on sex'. The Journal of Neuroscience. 30/35. 11576-11585. 
Bridge, D., Provyn, J.P., Zhang, Y. and Howard, M.W. (2006). 'Memory processes and gender influences: A matter of context.' Acta Psychologica, [Online] Available: http://memory.syr.edu/jennifer/papers/BridgeEtal-doc.pdf. (20 March 2011).

Bruning, R. H., Schraw, G. J., Norby, M. M. and Ronning, R. R. (2004). Cognitive psychology and instruction. (4th ed.). New Jersey: Pearson Education Limited.

Burman, D.D., Bitan, T. and Booth, J.R. (2008). 'Sex differences in neural processing of language among children.' Neuropsychologia. 46. 1349-1362.

Chaer, A. (2003). Psikolinguistik: Kajian teoretik (Psycholinguistics: Theoretical review). Jakarta: Rineka Cipta.

Cousin, E.; P. and Baciu. M. (2009). 'Hemispheric specialization for language according to grapho-phonemic transformation and gender: A divided visual field experiment.' $\underline{\text { Brain and }}$ $\begin{array}{llll}\text { Cognition. } & \text { 69(3). } & \text { 465-471. } & \text { [Online] }\end{array}$ http://www.sciencedirect.com/science? ob=ArticleURL\&_udi=B6WBY-4TY8WF31\&_user= $10 \&$ coverDate $=04 \% 2 \mathrm{~F} 30 \% 2 \mathrm{~F} 2009 \&$ rdoc $=1 \&$ fmt $=$ high $\&$ orig $=$ search $\&$ origin $=$ search $\&$ sort $=\mathrm{d} \&$ docanchor $=\&$ view $=\mathrm{c} \&$ acct $=\mathrm{C} 000050221 \&$ version $=1 \&$ urlVersion $=0 \&$ userid $=$ 10\&md5=b999b3fd26ea0218a70db238db79b48f\&searchtype=a. $(20$ March 2010).

Dardjowidjojo, S. (2003). Psikolinguistik: pengantar pemahaman bahasa manusia (Psycholinguistics: An introduction to understanding human language). (1st ed.). Jakarta: Yayasan Obor Indonesia.

dePorter, B, M. Reardon, and S. Singer-Nourie. (2000). Quantum teaching. Ary Nilandari (Tran.). Bandung: KAIFA.

Deux (1985). 'A review of psychological article.' [Online] Available: http://www. Docstoc.com/docs/16908042/(15 April 2010).

Duyek, B. J. (1996). Adolescent development and behaviour. (3rd ed.). DUYEK.

Ferguson, C.J., Cruz, A.M, and Rueda, S.M. (2007). 'Gender, video game playing habits and visual memory tasks.' Sex Roles @Springer Science Business Media.

Fernandez, E.M. and H.S. Cairns. (2011). Fundamentals of psycholinguistics. USA:Wiley-Blackwell.

Furchan, A. (1982). Metode penelitian pendidikan (Educational research methods). Yogyakarta: PUSTAKA PELAJAR.

Gallo-Crail and Zerwekh, R. (2002). 'Language learning and the internet: student strategies in vocabulary acquisition. In C.A. Spreen (Ed.) New technologies and language learning: cases 
in the less commonly taught languages. Honolulu: University of Hawaii, Second Language Teaching and Curriculum Center.

Iddon, J. and H. Williams. (2005). Memory boosters. Widyananto S. (Tran.). Memory Boosters Workout. (2003). London: Octopus.

Jensen, E. (2007). Brain-based learning. California: Corwin Press. Narulita Yusron (Tran.). Yogyakarta: Pustaka Pelajar.

Jewell, J. (2003). Kebugaran otak (Brain gym). Translated by Alexander Sindoro. Jakarta: Karisma.

Leopold, W. (2008). 'Boys' and girls' brain are different: Gender difference in language appear biological. Science Daily. [Online] Available: http://dx.doi.org/10.1016/j.neuropsychologia.2007.12.021 (21 November 2010).

Madaule, P. (2002). Earobics. Eva Y. Nukman dan Santi Indra Astuti (Trans.). Bandung: Kaifa.

Pease, A. and Pease, B. (2006). Why men don't listen and women can't read maps. Isma B. Koesalamwardi (Tran.). Jakarta: UFUK Press.

Press Trust of India. (2007). 'Men and women's brain acts differently.' [Online] Available: http://michellemiller.blogs.com/marketing_towomen/brain_studies/index.ht. (21 July 2007).

Proverbio, A. M., Brignone, V., Matarazzo, S., Zotto, M. D. and Zani, A. (2006). 'Gender differences in hemispheric asymmetry for face processing.' Neuroscience. 7(44). [Online] Available: http://www.ncbi.nlm.nih.gov/pmc/articles/PMC1523199/ (21 November 2010).

Rose, C. and Nicholl, M. J. (2003). Accelearted learning for the 21st century. Translated by Dedy Ahimsa. Bandung: Nuansa.

Rose, C. and Nicholl,M.J. (2006). Accelerated Learning for the $21^{\text {st }}$ century. Dedy Ahimsa (Tran.). Bandung: Nuansa.

Shellenberger, R.C. (2009). 'Sex differences in memorization: a study of visuo-spatial memory.' [Online] Available: http://clearinghouse.missouriwestern.edu/manuscripts/525.php (3 March 2011).

Speck, O., Ernst, T., Braun, J., Koch, C., Miller, E. and Chang, L. (2000). 'Gender differences in the functional organization of the brain for working memory.' Brain Imaging, NEURO REPORT. 2(2). 2581-2585. (C) Lippincott Williams \& Wilkins.

Steinberg, D.D., H. Nagata, and D.P. Aline. (2001). Psycholinguistics. Malaysia: Pearson Education. 
Sugiyono. (2003). Statistik nonparametris (Nonparametric statistics). Bandung: ALFABETA.

Suharsono. (2005). Melejitkan IQ, IE \& IS (Boosting IQ, IE \& IS). Jakarta: Inisiasi Press.

Yin, R. K. (2011). Qualitative research from start to finish. New York \& London: The Guildford Press. 